\title{
Seyhan Havzası Akım Verilerinin Hidrolojik Kuraklık Analizi
}

\author{
Mete Özfidaner ${ }^{1 *}$ \\ Duygu Șapolyo² \\ Fatih Topaloğlu²
}

\author{
'Alata Bahçe Kültürleri Araștırma Enstitüsü Müdürlüğü, Mersin \\ ${ }^{2}$ Çukurova Üniversitesi Ziraat Fakültesi Tarımsal Yapılar ve Sulama Bölümü, Adana
}

\begin{abstract}
*Sorumlu yazar e-mail (Corresponding author e-mail):mete.ozfidaner@tarim.gov.tr
Geliș tarihi (Received) : 06.02.2018

Kabul tarihi (Accepted): 07.02.2018

DOI : $10.21657 /$ topraksu.410140
\end{abstract}

\section{ÖZ}

Kuraklık, geniș alanlarda ve belirli bir zaman aralığında su kullanımının önemli derecede azalmasını karakterize eden doğal bir olaydır. Dünyanın değișik bölgelerinde meydana gelen kuraklık, ekonomik faaliyetleri, insan yașamı ve çeșitli çevresel etmenlere etki eder. Küresel hidrolojik çevrimin karmașık olması nedeni ile kuraklığın kökenini belirlemek mümkün olamamaktadır. Bu çalıșmada, Seyhan havzasında ölçülmüș olan aylık ortalama akımlar kullanılarak akarsu kuraklık indisi (SDI) metoduna göre kuraklığın saptanması hedeflenmiștir. Seyhan Havzası üzerinde bulunan 1801 ve 1818 nolu istasyonuna ait 1967-2007 yılları arası aylık toplam akım verileri kullanılmıștır. SDI metoduna göre 3, 6, 9,12 aylık dönemlerde kuraklık șiddetini ifade eden indeks değerleri elde edilmiștir. Her iki istasyonda da 9-12 aylık referans dönemleri için SDI değerleri benzer sonuçlar elde edilmiștir. 3 ve 6 aylık dönemlerde kuraklık değerleri 2000 yılından sonra önem kazanmıștır.

Anahtar Sözcükler: Kuraklık, Seyhan Havzası, Akım Kuraklık İndisi

\section{Hydrological Drought Analysis of Streamflow Data in Seyhan Basin}

\section{Abstract}

Drought is natural event which symbolizes the significant decrease in usage of water in wide field and specific time. Drought, which occurs in different areas of world, effects economical activities, human's lives and different environmental factors. Complexity of global hydrological cycle obstructs finding the reason of drought. This study was intend to determine drought of the basin by using mean monthly straemflows in Seyhan basin in streamflow drouht index (SDI). In this reason, mean monthly streamflows gauge for 1967-2007 in flow station 1801-1818 number located on Seyhan river was used. According to SDI method 3, 6, 9,12 months in the index values were obtained expressing the drought severity. SDI values for each station in the 9-12-month reference period were obtained similar results. 3 and 6 months of drought values have gained importance after 2000.

Keywords: Drought, Seyhan basin, Streamflow Drouht Index.

\section{Giriș}

Kuraklık, geniș alanlarda ve belirli bir zaman aralığında su kullanımının önemli derecede azalmasını karakterize eden doğal bir olaydır. Dünyanın değișik bölgelerinde meydana gelen kuraklık, ekonomik faaliyetlere, insan yașamına ve çeșitli çevresel etmenlere etki eder. Çok yavaș gelișerek belirli bir süreçte olușan kuraklık olayın süresi uzadıkça sonuçları da çok tehlikeli boyutlara ulașmaktadır (Kömüșçü, 2001). Kuraklığın önemli zararı ise nehirlerin kuruması veya suyun azalması ile doğal yașamın zorlașmasıdır. Kurak ve yarı kurak iklim özelliğine ait alanlarda 
akarsuların verimleriyle ilgili bilgiler, kullanma ve sulama suyu, sulama zamanının belirlenmesi ve rezervuar ișletilmesi açısından önemlidir. Akarsu havzasında yağıșlarda meydana gelecek değișim direkt olarak akarsu akımlarını da etkileyecektir (Yürekli ve vd, 2009).

Kuraklık bașta meteorolojik kuraklık olmak üzere, hidrolojik, tarımsal ve sosyo-ekonomik kuraklık olarak kendini gösterir. Meteorolojik kuraklık uzun bir zaman içinde yağıșın belirgin șekilde normal değerlerin altına düșmesi olarak tanımlanır. Toprakta özellikle büyüme döneminde bitkinin ihtiyacını karșılayacak miktarda su bulunmaması olarak tanımlanan tarımsal kuraklık nem kaybı ve su kaynaklarında kıtık oluștuğu zaman meydana gelir. Hidrolojik kuraklık ise yeraltı su kaynakları, yüzey suları veya yağıș dönemlerinin etkisi ile ilișkili olup uzun süreli yağıș azlığının kaynak seviyeleri, yüzey akıșı ve toprak nemi gibi hidrolojik sistemin bileșenlerinde kendisini göstermesidir. Kuraklığın sosyo-ekonomik tanımı meteorolojik, tarımsal ve hidrolojik kuraklıkla bağlantılı bazı ekonomik ürünlerin arz ve talepleriyle ilgilidir.

Nehir akımları yağıș, buharlașma, terleme ve hidrolojik döngü bileșenlerinin diğer kısımları ile birlikte olası insan kaynaklı etkilerin bir bileșimi sonucu meydana gelmektedir. Hidrolojik döngü bileșenlerindeki değișimler tașkın/sel ve kuraklık șeklinde yansıyarak insan yașamını doğrudan etkileyebilmektedir. İnsan yașamı iklimsel değișikliklerden, doğal sistemlerin bu değișimlere karșı duyarlııkları oranında etkilenecektir. Su kaynakları, hidrolojik döngüyle ilișkileri nedeniyle, iklimsel değișikliklerden doğrudan etkilenecek doğal sistemleri olușturmakta ve insanın suya olan ihtiyacı içme-kullanma ile sınırlı kalmamaktadır. Tarımsal üretim için suya olan ihtiyacın birincil olduğu dikkate alındığında su kaynaklarının nitelik ve niceliğinde meydana gelebilecek değișikliklerin önceden kestirilmesinin etkin-sürdürülebilir kalkınma açısından önemi daha da artmaktadır.

Dünya ve ülkemizde bugüne kadar çeșitli amaçlara yönelik olarak kuraklık araștırmaları yapılmıștır. Genelde kuraklık olayına araștırmacılar kendi uzmanlıkları açısından yaklașmıșlardır. Bunlardan; Kemali ve Nikzad (1990); Rüstemifer (1997), Kayam ve Çetin (2012) tarımsal kuraklık, Özkan (2001); Fereczadeh vd. (2001), Özfidaner (2007), Türkeș (1990), (2002); Türkeș ve Tatlı (2009), Sırdaș (2002); Sırdaș ve Sen (2003); Loukas vd. (2004); Pamuk vd., (2004) meteorolojik kuraklık ve Erdoğan (1989); Köse vd. (2002); Siyadeti ve Ensari (2001); Nalbantis and Tsakiris (2009); Yürekli vd.(2009) Kıymaz vd. (2011) Topaloğlu,(2006a,b); Topaloğlu vd. (2012) ise hidrolojik kuraklık konularında çalıșmalar yapmıșlardır.

Kuraklık ile ilgili tanımlarda en belirgin problemlerden biri kurak dönem süresi boyunca yağıș eksikliğinin yeraltı suları, su rezervuarları, toprak nemi, kar kütleleri ve nehir akımlar gibi farklı su kaynaklarına nasıl etki ettiğidir (Turgu ve Kömüșcü, 2010). Burada en önemli sorun yağıș eksikliğinden kaynaklanan akımlarda meydana gelebilecek kuraklığın bu kaynaklar üzerindeki etkisinin süre ve șiddetlilik açısından farklı olmasından kaynaklanmasıdır. Bu durumda kuraklığın izlenmesi açısından akım verilerinin farklı zaman dilimleri içinde niceliksel olarak ifade edilmesi gerekliliği ortaya çıkmaktadır.

Seyhan havzası iklim değișikliğinden dolayısı ile kuraklıktan önemli derecede etkilenecek havzaların bașında gelmektedir. Mevcut su potansiyeli ve ürün deseninde ki farklılık ve yoğunlukkuraklıkileberaber değișiklikgösterebilir. Seyhan havzasında yapılan çeșitli çalıșmalar sonucunda Seyhan havzası'nda aylık ortalama sıcaklıkların $3^{\circ} \mathrm{C}$ artacağı; yıllık yağıș miktarında ise \%25'lik bir azalma olacağı saptanmıstır. Potansiyel evapotranspirasyonda \%14'lük bir artıș, buna karșı gerçek evapotranspirasyonda ise, yağıșın azalmasına bağlı olarak, \%17'lik bir azalıșın olacağı kestirilmiștir. Araștırma, iklim değișikliklerinin, Seyhan Havzası su kaynaklarında bir azalmaya neden olacağını göstermektedir. Yüzey suyu kaynakları, kar depolaması ve yeraltı suyu potansiyelinde \%30'a varan önemli düșüșler gerçekleșecektir (Kanber vd. 2007). Yağıșlardaki azalmanın Ocak, Nisan, Ekim, Kasım ve Aralık aylarında daha fazla olacağı kestirilmiștir (Kimura, 2005; Kimura ve ark., 2006). Yüzey su kaynakları, kar depolaması ve yeraltı suyu potansiyelinde \%30'a varan önemli azalıșların gerçekleșeceği kestirilmektedir (Ekmekçi, 2008; Tezcan ve ark., 2007).

Bu çalıșmanın amacı Seyhan Havzasında Ölçülmüș olan 1801 ve 1818 nolu Akım Gözlem İstasyonlarından elde edilen aylık toplam akım verilerinden Akım Kurakık İndisi (SDI). Yöntemi ile 3, 6, 9, 12 aylık kuraklık değerlerini belirlemektir. 


\section{Materyal ve Yöntem}

Türkiye'nin batısında, Çukurova'dan kuzeye doğru kama biçiminde uzanan Seyhan Havzası'nın, yukarı bölümü İç Anadolu, orta ve așağı bölümü Akdeniz Bölgesi'nde yer almaktadır. Seyhan Nehri ile Göksu ve Zamantı kollarının su toplama alanlarını içeren havza, $36^{\circ} 33^{\prime}-39^{\circ}$

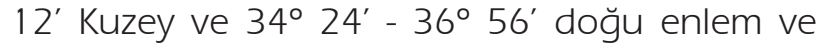
boylam dereceleri arasındadır. Havza 2.213.415 hektar genișlikte olup, Türkiye'nin \%2,82'sini kapsamaktadır. Toplam yağıș alanı 20.731 km² olan Seyhan Havzası'nın yıllık ortalama yağıș yüksekliği $624 \mathrm{~mm}$; yıllık ortalama akıșı ise 211,07 $\mathrm{m}^{3} \mathrm{~s}^{-1}$ dir. Yıllık ortalama verimi 10,18 $\mathrm{L}^{-1} \mathrm{~km}^{3}$ olan havzadaki akıșın yağıșa oranı 0,51 iken, iștirak oranı \%3,62' dir Havza farklı tarımsal ișlevleri kapsamaktadır. Havzanın üst ve orta bölümlerinde kuru, așağı kesimlerde ise sulu tarım yapılmaktadır. Her iki kesimde de önemli tarımsal ürünler, örneğin, buğday, mısır, meyve ve sebze yetiștirilmektedir. Havzanın büyük bir bölümü

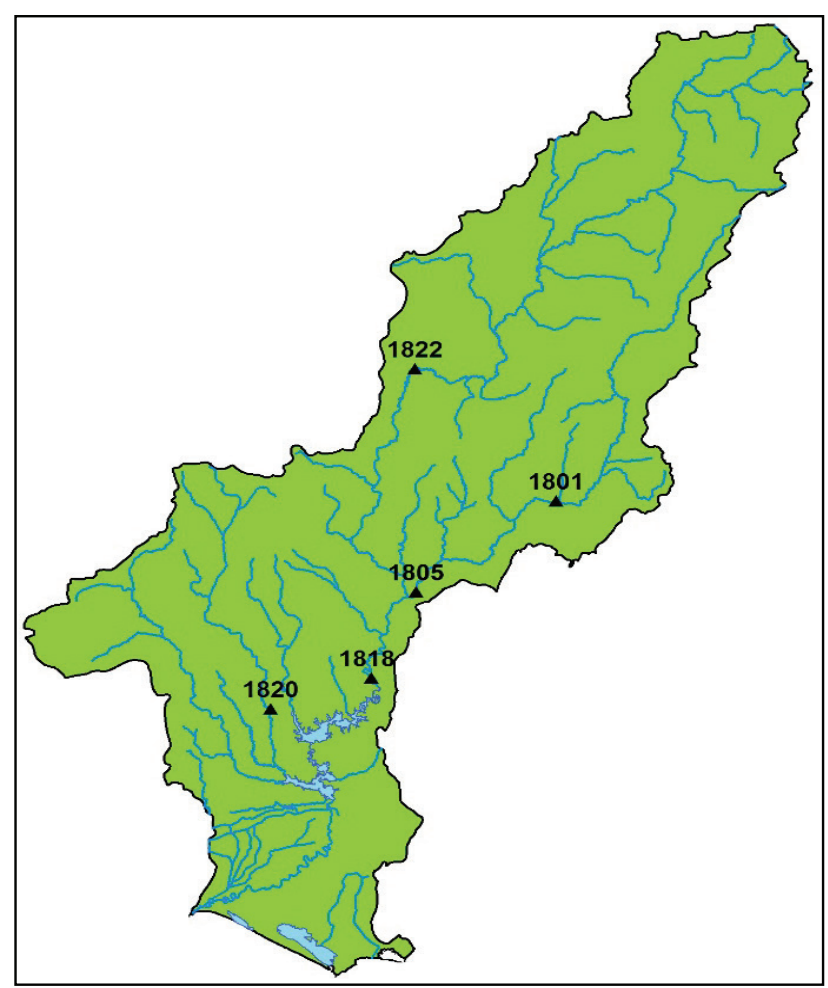

Șekil 1. Seyhan havzası akım gözlem istasyon konumları

Figure 1. Gauging stations locations of Seyhan basin

Çizelge 1. Seyhan havzası istasyonların özellikleri

Table 1. Properties of Seyhan basin stations

\begin{tabular}{ccccccc}
\hline İstasyon No & İstasyon Adı & Rasat Yılları & Enlem & Boylam & Kot (m) & Drenaj Alanı (km²) \\
\hline 1801 & Göksu-Himmetli & $1967-2007$ & $37051^{\prime}$ 59“ & 360 03’32“ & 665 & 2596.8 \\
\hline 1818 & Seyhan-Üçtepe & $1967-2007$ & $37022^{\prime} 47^{\prime \prime}$ & 350 28’ 07“ & 130 & 13846 \\
\hline
\end{tabular}

kıșlık ortalama yağıșı 700 mm olan Akdeniz iklim kușağında yer almaktadır. İlkbahar ve kıș yağıșları büyük su yapılarında tutulmakta; sulama ve enerji üretimi için kullanılmaktadır. Havzanın Türkiye ve Avrupa için önemli bir gıda üretim alanı sayılması; üst havza kesimlerde yaygın bir hayvancılık ve çayır-meracılık yapılması; buğday gibi çok stratejik bir ürünün, havzada çok uzun bir geçmișe sahip olması; ve havzanın tümünün ulusal sınırlar içerisinde bulunması gibi ögeler sayılabilir.

Araștırmada Akım kuraklık indisi (SDI) yöntemiyle Seyhan Havzasında kuraklık olușumunun analiz seçilen istasyonlara (1801-1818) ait bilgiler Çizelge I'de verilmiștir. Bu amaçla bölgede yer alan istasyonların 1967-2007 dönemine ait ortalama akım değerleri DSi'nden temin edilmiștir.

\section{Akım değerlerinin Akarsu Kuraklık İndeksi (SDI) Yöntemi ile Belirlenmesi}

Hidrolojik kuraklık indisi olarak bilinen akarsu kuraklık indisi Nalbantis ve Tsakiris (2009) de verilen ilișkilere göre belirlenir. Herhangi bir hidrolojik yılı (i) bu yılın bir ayını (j), akımı ise $\mathrm{O}_{\mathrm{ij}}$ ile tanımlanırsa, kümülatif akarsu akımlarına $\left(\mathrm{V}_{i, k}\right)$ ait zaman serisi eșitlik 1 den elde edilir:

$V_{i, k}=\sum_{j=1}^{3 k} Q_{i j} \quad i=1,2 . . N j=1,2, . ., 12 k=1,2,3,4$ Eșitlik (1)

Vi,k, hidrolojik yılın k-referans periyodu için kümülatif akım miktarını vermektedir. $N$ hidrolojik yıl sayısını belirtmektedir. K-referans periyodu $k=1$ olduğunda Ekim-Aralık dönemini, k=2 olduğunda Ekim-Mart dönemini, k=3 olduğunda, EkimHaziran dönemini ve k=4 olduğunda Ekim-Eylül dönemini yansıtmaktadır. Burada Ekim-Eylül dönemine ait kümülatif akımlar yıllık akımları temsil etmektedir.

SDI değerleri, kümülatif akarsu akımlarına (Vi,k) göre așağıda verilen eșitlik 2 den, her k-referans periyoduna bağlı olarak her hidrolojik yıl için dört defa elde edilir.

$S D I_{i, k}=\frac{V_{i, k}-\overline{V_{k}}}{S} \quad i=1,2 . . \mathrm{N} j=1,2, . ., 12 \quad \mathrm{k}=1,2,3,4$ Eșitlik (2) edilebilmesi için konumları Șekil l'de konumları 
$\overline{V_{k}}$ ve S, k-referans periyodu için kümülatif akarsu akımlarının ortalama ve standart sapma miktarlarını vermektedir. Kurak olmayan ile așırı kurak olarak tanımlanan 5 tane kuraklık sınıflandırılması Çizelge 2 de verilmiștir.

Çizelge 2. Akarsu Kuraklık Sınıfları (SDI)

Table 2. Streamflow drought classes (SDI)

\begin{tabular}{ccc}
\hline Durum & Kuraklık Tanımı & AKI \\
0 & Kuraklık yok & AKI $\geq 0.00$ \\
1 & Hafif kurak & $-1.0 \leq \mathrm{AKI}<0.0$ \\
2 & Orta derece kurak & $-1.5 \leq \mathrm{AKI}<-1.0$ \\
3 & Siddetli kurak & $-2.0 \leq \mathrm{AKI}<-1.5$ \\
4 & Așırı kurak & $\mathrm{AKI}<-2.0$ \\
\hline
\end{tabular}

\section{Bulgular ve Tartıșma}

Seyhan Havzası 1801-1818 nolu akım gözlem istasyonlarına ait 1967-2007 yılları arasındaki aylık akım verilerinin Akım kuraklık indisi (SDI) sonuçları așağıda verilmiștir.

Seyhan havzası 1801 nolu akım gözlem istasyonlarının hidrolojik yıl için referans dönemlerine ait elde edilen AKí değerlerinin grafikleri 3-6 aylık dönemler için Șekil 2 de, 6-9 aylık dönemler için Șekil 3 de, 9-12 aylık dönemler için Șekil 4 de verilmiștir. Șekil 2 incelendiği zaman 3 ve 6 aylık dönemlerde kuraklık değerlerinde farklılık belirlenmiștir. Nalbantis ve ark 2009 çalıșmasında bu durum için Akdeniz bölgesinin karakteristik bir özelliği olduğunu belirtmișlerdir. Akdeniz Bölgesinde genellikle 6 aylık dönemlerde ıslak dönemlerin olabileceği öngörülmüștür. Özellikle 2002-2007 ylından sonra 6 aylık kaydırma dönemlerinde kuraklığın olmadığı fakat 3 aylık dönemlerde hafif kuraklık yașandığı gözlemlenmiștir. Anılan dönemlerde sadece 6 aylık kaydırmada 2007 yılında orta derecede kuraklık olduğu belirlenmiștir. Benzer sonuçlar Yürekli ve ark. (2009) Sakarya havzasında yaptıkları çalıșma da belirtmișleridir.

Șekil 3 (6-9 ay) ve Șekil 4 (9-12 ay) incelendiği zaman kuraklık değerleri bakımından herhangi bir fark bulunmamıștır. Akarsu kuraklık indisi değerleri bakımından 9 ve 12 aylık kaydırma değerleri birbirinin benzeri bulunmuștur. Bu durum Akdeniz bölgesinin ikinci 6 aylık dönemlerinin kurak olabileceğini göstermektedir. Benzer bir sonuç Nalbantis vd. (2009) ve Yürekli vd. (2009) tarafından da belirlenmiștir. Ortaya çıkan sonuç 12 aylık kaydırma durumunda SDI değerleri kuraklığın olduğunu göstermektedir. Uzun dönemli dönemlerde akımlarda meydana gelen değișiklik kuraklığı tetikleyen bir olgudur. Öztürk vd. (2010) Doğu Karadeniz havzasında yaptıkları çalıșmada 12 aylık Akım kuraklık indislerinde inceledikleri 8 istasyonun son 5 yıllık dönemlerde 4 istasyonda kuraklık belirlemișlerdir.

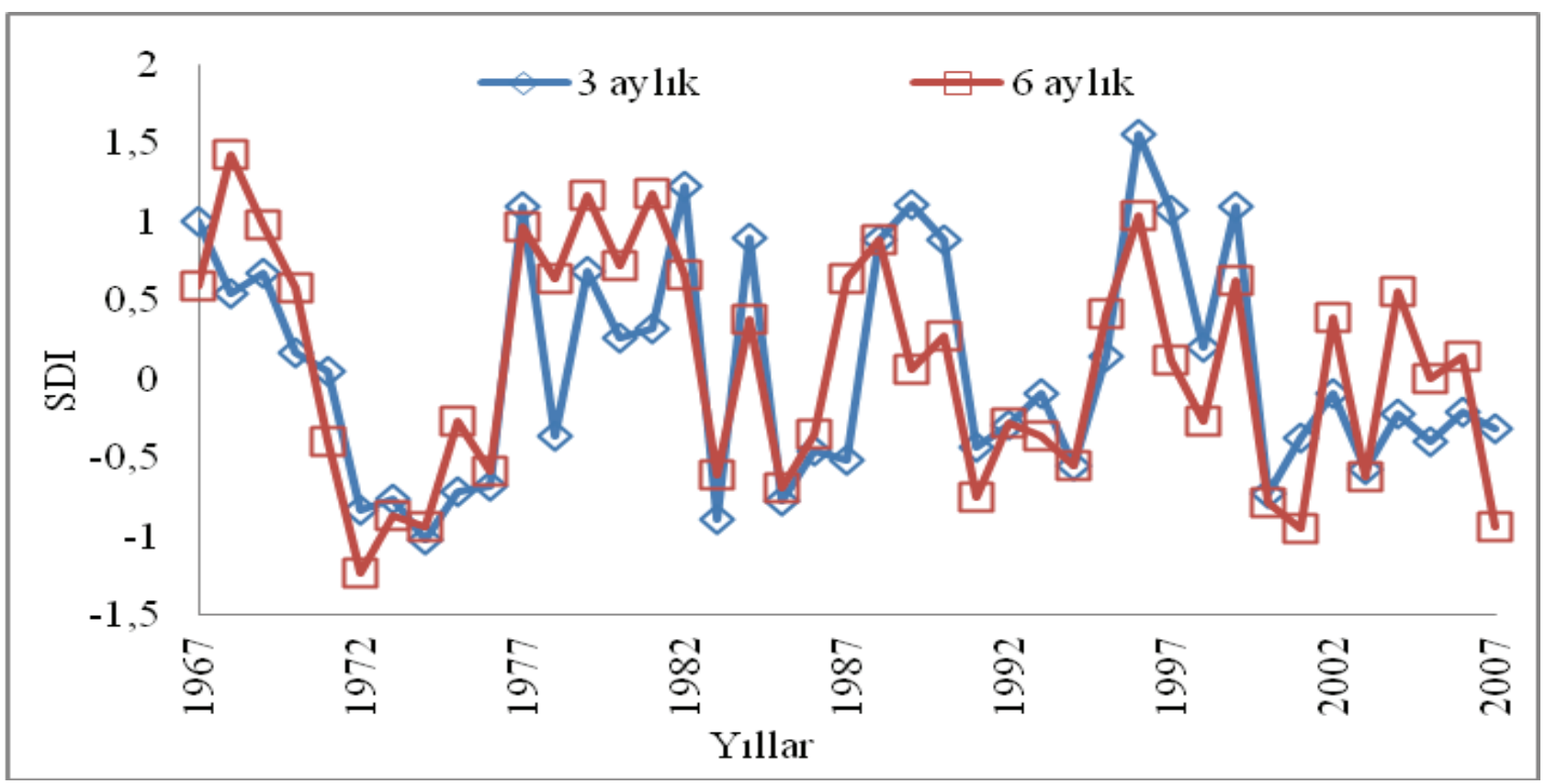

Șekil 2. Ekim-Aralık ve Ekim-Mart referans dönemleri için SDI değerleri (1801)

Figure 2. The SDI values for the reference periods October-December and October-March (1801) 


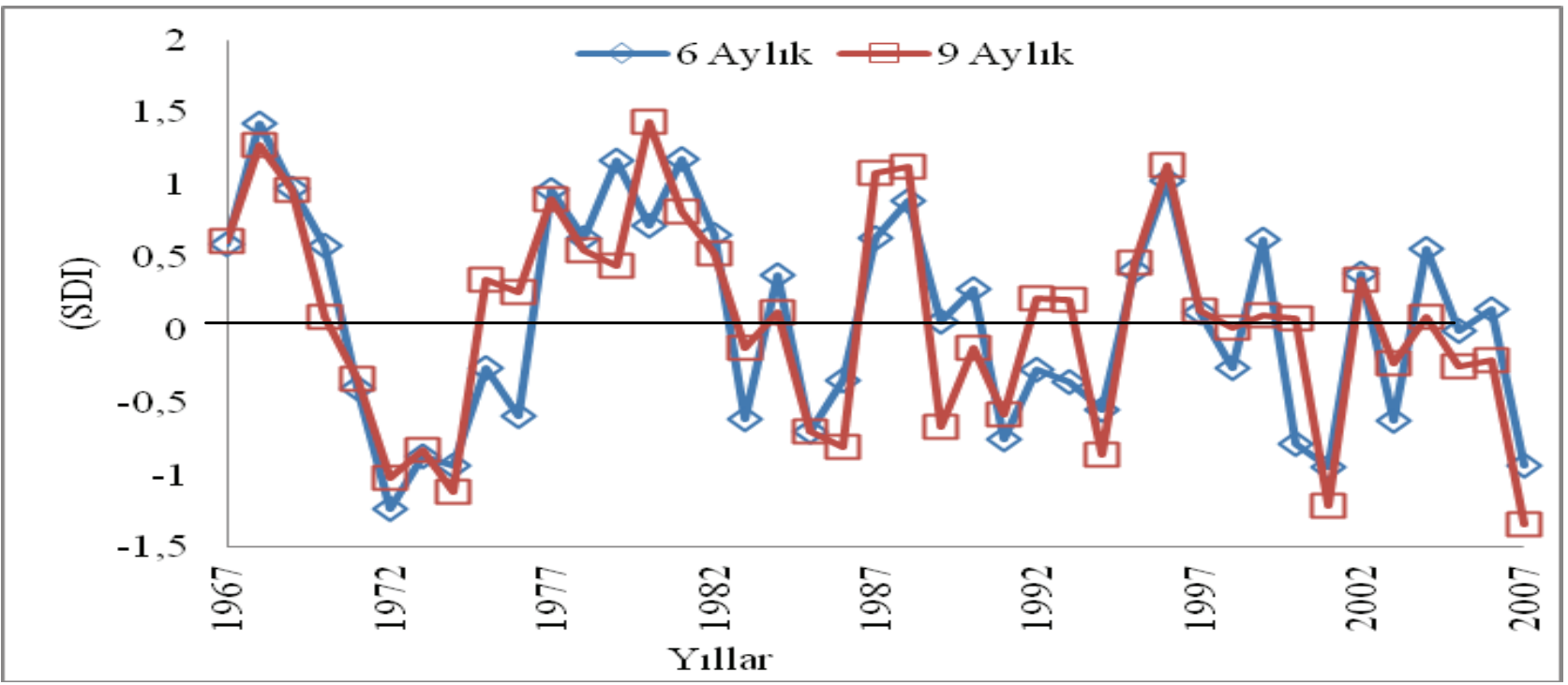

Șekil 3. Ekim-Mart ve Ekim Haziran referans dönemleri için SDI değerleri (1801)

Figure 3. The SDI values for the reference periods October-March and October June (1801)

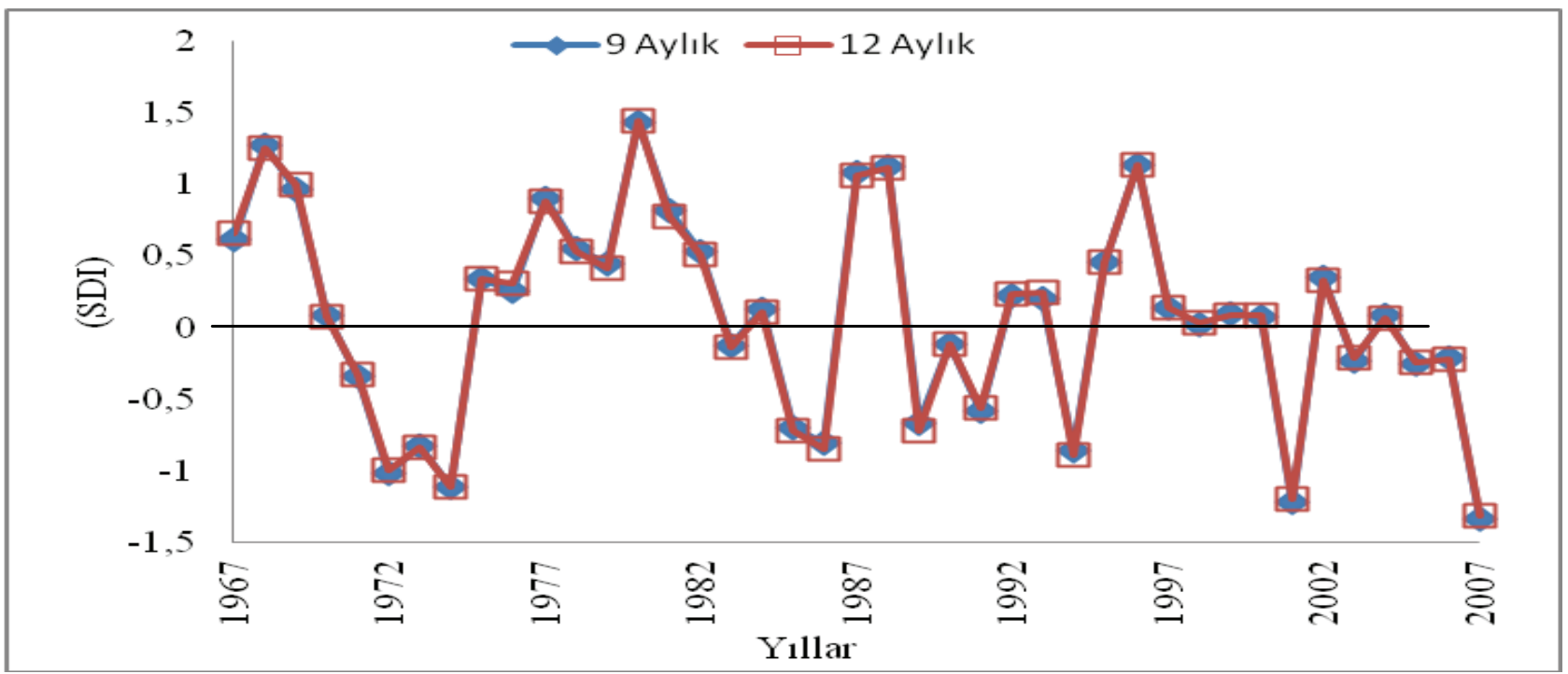

Șekil 4. Ekim-Haziran ve Ekim-Eylül referans dönemleri için SDI değerleri (1801)

Figure 4. The SDI values for the reference periods October-June and October-September (1801)

Seyhan havzası 1801 nolu akım gözlem istasyonu verilerinin akım kuraklık indis değerleri farklı referans periyotları için incelendiği zaman hidrolojik kuraklığın son yıllarda fazlasıyla hissedildiği sonucuna varılmaktadır. Özellikle 2000 yılından itibaren 3 aylık referans döneminde kuraklık olduğu belirlenmiștir. 3 ve 6 aylık referans dönemlerinde 5 er yıl ara ile kurak ve Islak dönemler belirlenmiștir. 9 ve 12 aylık referans döneminde incelenen ylllar itibarı ile 2002 ve sonrası dönemlerde kuraklık șiddetinin arttığı gözlemlenmiștir.
Seyhan havzası 1818 nolu akım gözlem istasyonlarının hidrolojikyıl için referans dönemlerine ait elde edilen SDI değerlerinin grafikleri 3-6 aylık dönemler için șekil 5 de, 6-9 ayllk dönemler için Șekil 6 da, 9-12 aylık dönemler Șekil 7 de verilmiștir. Șekil 5'de 1818 nolu akım gözlem istasyonundan elde edilen SDI değerlerinin 3 ve 6 aylık referans dönemleri görülmektedir. 1801 nolu istasyonda benzer sonuçlar elde edilmiștir. 1972-1979 ile 20002007 yılları arasında 3 aylık referans dönemlerde kuraklık belirlenmiștir. Kısa dönemli bu kuraklık değerleri akım verileri için önemli bir noktaya sahiptir. Seyhan havzasında yoğun olarak yapılan tarımsal faaliyetler kuraklıktan dolayı etkilenecektir. 


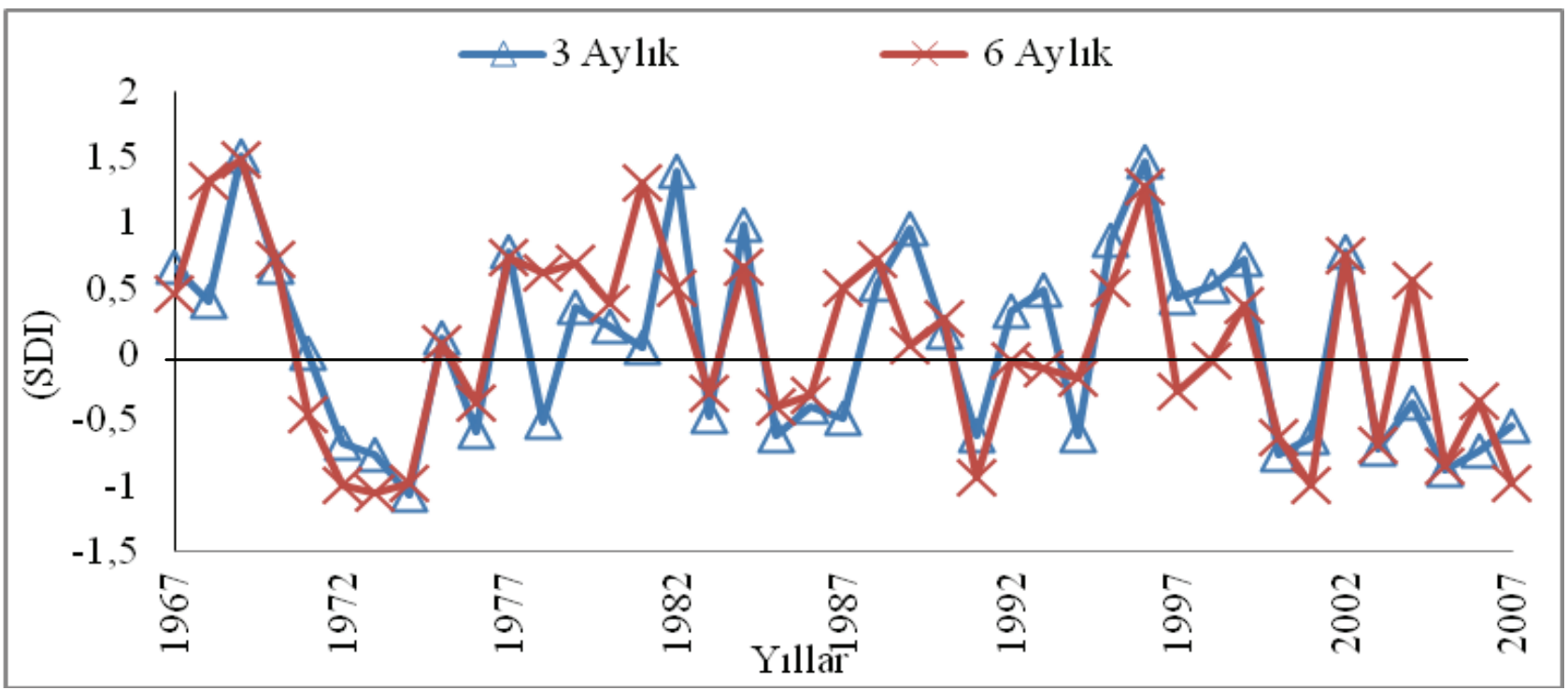

Șekil 5. Ekim-Mart ve Ekim Haziran referans dönemleri için SDI değerleri (1818)

Figure 5. The SDI values for the reference periods October-March and October-june (1818)

Seyhan havzası 1818 nolu akım gözlem istasyonu 6-9 aylık referans dönem sonuçları șekil 6 da verilmiștir. Anılan dönemler için grafiktende görüleceği gibi kuraklık süresi artıkça SDI değerleride büyümektedir. Yani kuraklıgın süresi arttıkça șiddeti de artmaktadır. Tuna vd. (2009) da Coruh Havzası içerisinde bulunan 7 Akım Gözlem istasyonuna ait 1963-2008 dönemi aylık ortalama debi değerlerini kullanılarak, SDı yöntemine göre havzanın hidrolojik kuraklık analizini yapmıșlar. Akım gözlem istasyonları için 1983, 1984, 2000, 2001 ve 2002 su yılarında çok șiddetli kuraklık saptamıșlardır.

Sekil 7 de Seyhan havzası Akarsu kuraklık indisi değerleri bakımından 9 ve 12 aylık kaydırma değerleri birbirinin benzeri bulunmuștur. Benzer durum 1801 nolu istasyonda da mevcuttur. Bu durum Akdeniz Bölgesinin ikinci 6 aylık dönemlerinin kurak olabileceğini göstermektedir. Uzun dönemlik kaydırma durumlarında ortaya çıkan kuraklık nehir akımlarında azalıșın olduğunu göstermektedir. Bunun nedeni olarak ta havzaya düșen yağıșlarda bir azalmanın olduğu ve bu azalma ile birlikte nehir haznesinin istenilen düzeye gelmediğinin göstergesidir.

Akım eksikliğine bağlı olarak hesaplanan Kuraklığın küresel boyutta yașanan iklimsel farklıık ve değișimler nedeniyle son yıllarda dünyada ve ülkemizde de çok ciddi bir tehdit olușturduğu

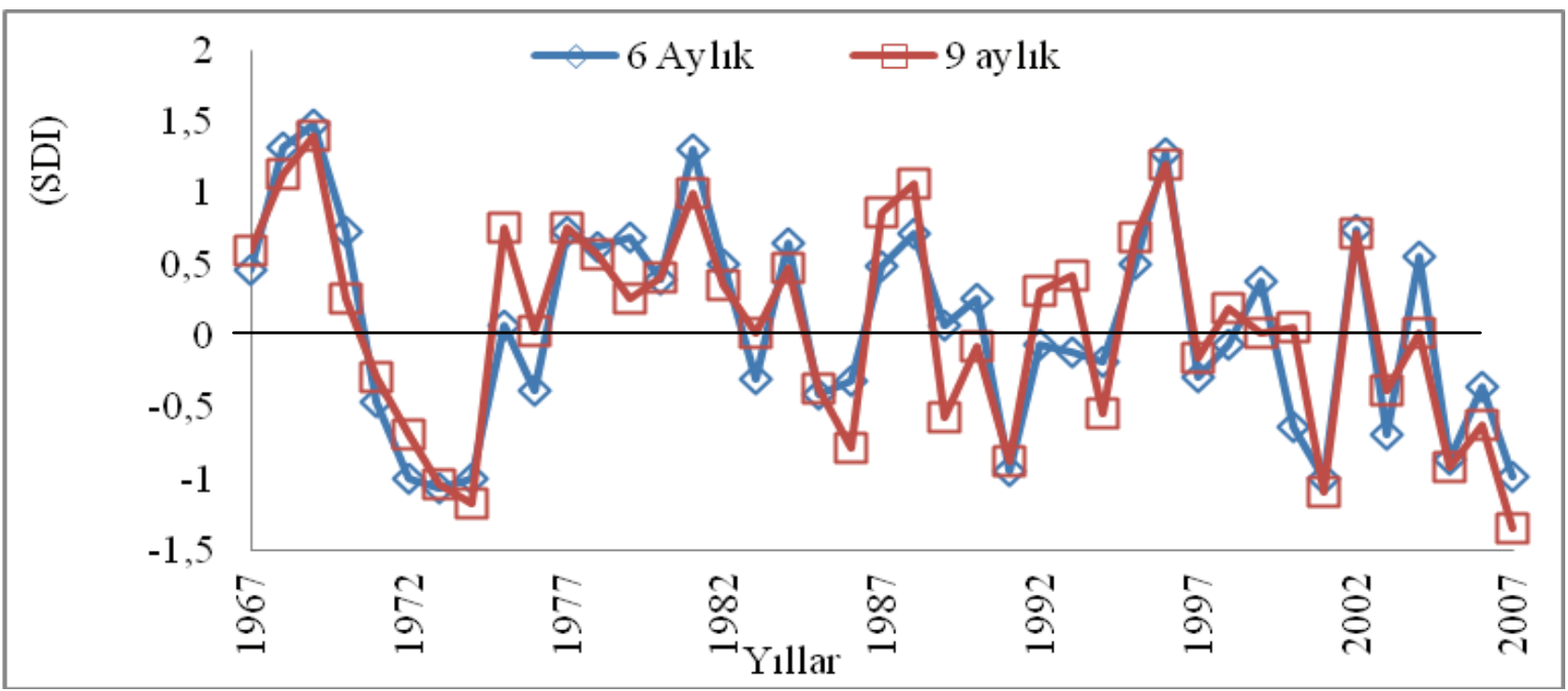

Șekil 6. Ekim-Mart ve Ekim Haziran referans dönemleri için SDI değerleri (1818)

Figure $\mathbf{6}$. The SDI values for the reference periods October-March and October-june (1818) 


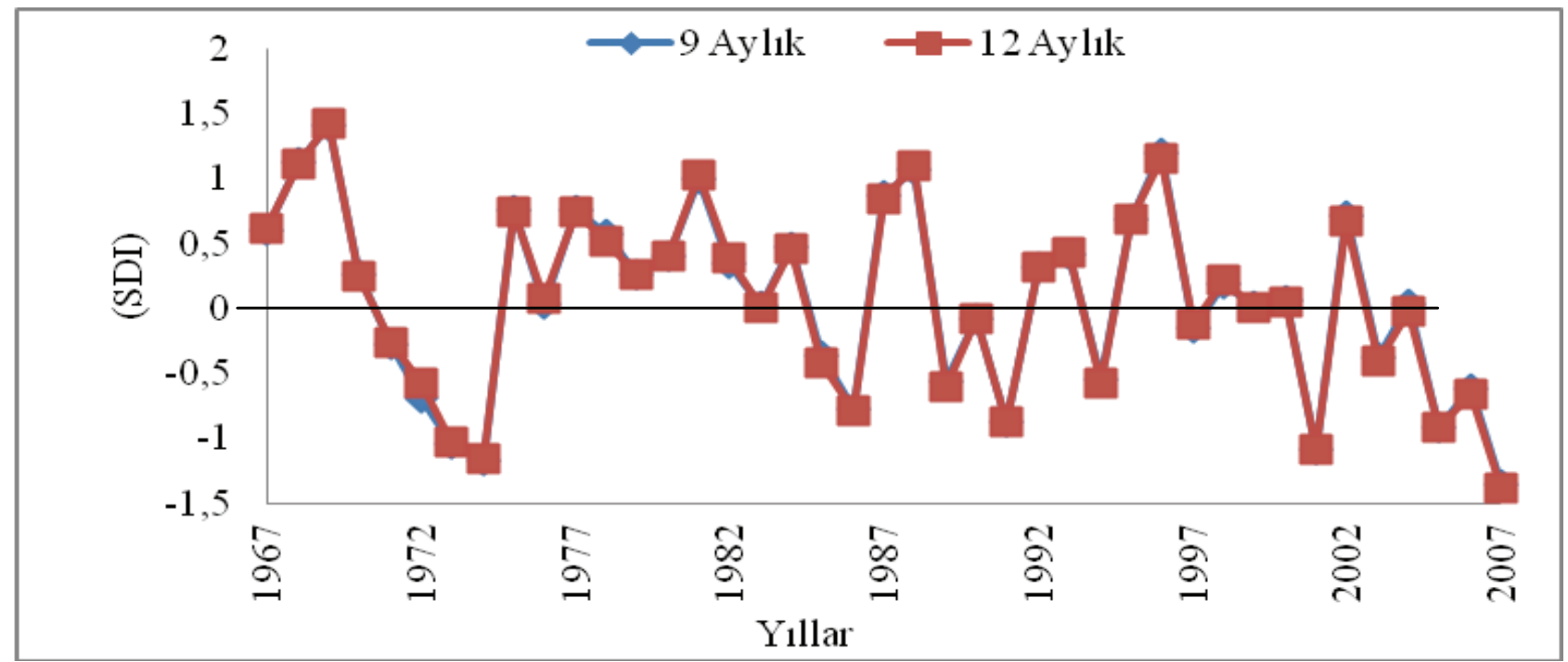

Șekil 7. Ekim-Haziran ve Ekim-Eylül referans dönemleri için SDI değerleri (1818)

Figure 7. The SDI values for the reference periods October-June and October-September (1818)

görülmektedir. Bu nedenle, kuraklığın bir merkez tarafından izlenmesi ve her sektör için kuraklık eylem planlarının hazırlanması gerekmektedir. Ayrıca, meteorolojik kuraklık çalıșmalarının su kaynaklarının izlenmesi, etkilerinin belirlenmesi ve yönetim modellerinin olușturulması açısından ele alınması önerilir (Kıymaz vd. 2011 ).

Akım eksikliğine bağlı olarak hesaplanan Kuraklığın küresel boyutta yașanan iklimsel farklılık ve değișimler nedeniyle son yıllarda dünyada ve ülkemizde de çok ciddi bir tehdit olușturduğu görülmektedir. Bu nedenle, kuraklığın bir merkez tarafından izlenmesi ve her sektör için kuraklık eylem planlarının hazırlanması gerekmektedir. Ayrıca, meteorolojik kuraklık çalıșmalarının su kaynaklarının izlenmesi, etkilerinin belirlenmesi ve yönetim modellerinin olușturulması açısından ele alınması önerilir (Kıymaz vd. 2011 ).

\section{Kaynaklar}

Ekmekçi, M., 2008. Jeolojik Geçmișten Günümüze İklim Değișiklikleri: Küresel İklim Değișimi ve Türkiye. TMMOB İklim Değișimi Sempozyumu. 13-14 Mart, 2008, Ankara, s. 7-26

Erdoğan, F. 1989. Türkiye'de Yaygın Kuraklık, Meteoroloji Mühendisleri Odası Bülteni 2:1-4.

Fereczadeh, M. 2001. Kuraklık Olayına Karșı Olan Bazı Yeni Önlemler ve Yöntemleri. Drought. FC. 777-786.

Kanber, R., Kapur, B., Ünlü, M., Koç, D.L., Tekin, S., 2007. İklim Değișiminin Tarımsal Üretim Sistemleri Üzerine Etkisinin Değerlendirilmesine Yönelik Yeni Bir Yaklașım: ICCAP Projesi. Öıçü Dergisi, 2007, Eylül sayısı, s. 44-49

Kayam, Y., O, Cetin. 2012. The Impact of Drought and Mitigation Strategies in Turkey, BALWOIS 2012 - Ohrid, Republic of Macedonia - 28 May-2June 2012.
Kemali, K. ve Nikzad, M. 1990. Tarımsal Kuraklıkla İlgili Meteorolojik İndeksler. Nivar Dergisi. Kıș 1990 9-19.

Kıymaz, S., Güneș, V., Așar, M. 2011 . Standartlaștırılmıș Yağıș Indeksi İle Seyfe Gölünün Kuraklık Dönemlerinin Belirlenmesi. GOÜ, Ziraat Fakültesi Dergisi, 28(1), 91-102.

Kimura, F., 2005: Trend in precipitation during the next 80 years in Turkey estimated by pseudo warming experiment. In: ResearchTeam for the ICCAP Project (ed.), The Progress Report of ICCAP, Research Institute for Humanity and Nature, Kyoto, Japan, 11-12

Kimura, F., Kitoh, A., Sumi, A., Asanuma, J., Tatagai, A., 2006. An assessment for downscaling methods for global warming in Turkey, The Advance Report of the Research Project on the Impact of Climate Changes on Agricultural Production System in Arid Areas, 11-14.

Kömüșçü, A.U. 2001. An Analysis of Recent Drought Conditions in Turkey in Relation to Circulation Patterns. Drought Network News, (13) 5-6

Köse, Ö ve Dorum, A. 2002. Orta Anadolu Kapalı Havzası Kuraklık Parametrelerinin Olasıılık Dağılımı. Turkish J. Eng. Env. Sci. 26 , 85-93. с TÜBITAK.

Loukas, A.and Vasiliades, L. 2004. Probabilistic analysis of drought spatiotemporal characteristics inThessaly region, Greece. Natural Hazards and Earth System Science, Copernicus Publications on behalf of the European Geosciences Union, 4 (5/6), pp.719-731

Nalbantıs, I. and Tsakiris, G. 2009. Assessment of Hydrological Drought Revisited. Water Resource Management 23:881-897

Özfidaner, M. (2007). Türkiye Yağıș Verilerinin Trend Analizi ve Nehir Akımları Üzerine Etkisi. C..Ü. Fen Bil. Enstitüsü Tarımsal Yapılar ve Sulama Anabilim Dalı, Yüksek Lisans Tezi, No: 3061, Adana, 73s.

Özkan, K. 2001. Eğirdir Gölü Havzası'nın Kuraklık Etüdü ve Tarım-Ormancılık Açısından Değerlendirmesi. Süleyman Demirel Üniversitesi. Orman Fakültesi Dergisi. Seri: A, Sayı 2, 2001,ISSN: 1320-7085, 75-96. 
Öztürk ,D., Malkoç, F., Tuna, H. 2010. Doğu Karadeniz Havzasında SYi İle Kuraklık Analizi ve Çevresel Etkileri. VI. Ulusal Hidroloji Kongresi, Pamukkale Üniversitesi, Denizli. 3243

Pamuk, G., Özgürel, M. ve Topçuoğlu, K. 2004. Standart Yağıș İndisi (SYI) ile Ege Bölgesinde Kuraklık Analizi. Ege Üniv. Ziraat Fak. Dergisi. 2004, 41 (1):99-106

Rustemifer, F.F. 1997. 1990'ın Onluğunda Kuraklık Olayı. Bahar 1997. 19-28. İran.

Sırdaș, S. ve Șen, Z. 2003. Meteorolojik kuraklık modellemesi ve Türkiye uygulaması. ITU Dergisi/D Mühendislik 2(2), 95-103.

Sırdaș, S., (2002). Meteorolojik Kuraklık Modellemesi ve Türkiye Uygulamaları, ITÜ Fen Bilimleri Enstitüsü (Doktora Tezi), İstanbul. p. 260

Tezcan, L., Ekmekçi, M., Atilla, Ö., Gürkan, D., Yalçınkaya, O., Otgonbayar, N., Saylu, M.E., Donma, S., Yılmazer, D., Akyatan, A.,Pelen, N., Topaloglu, F., İrvem, A., 2007. Seyhan Nehri Havzasında Tarım Güvenliği İçin Su Kaynakları Sistemlerinin İklim Değișikliğine Karșı Duyarılıklarının Araștırılması. ICCAP Projesi Türk Grubu Sonuç Raporları, Kyoto, s. 1-24

Siyadeti, S. B. ve Ensari, J. 2001. Erak Çölünde Yeraltı Su Kaynaklarına Kuraklık Olayının Etkisi. Preceding of First National Conference on Drought Mitigation and Water Shortage. S.736-741

Topaloglu, F.; Irvem, A.; ve Özfidaner. M. 2012. Reevaluation of Trends in annual streamflows of Turkish rivers for the period 1968-2007. Fresenius Environmental Bulletin .21 (8): 2043-2050

Topaloğlu, F. 2001. Yağıș Verilerinin İstatistiksel Ön Analizleri: Seyhan Havzası Örneği. I. Türkiye Su Kongresi, 8-10 Ocak 2001, İstanbul, Cilt I.
Topaloğlu, F. 2006a. Regınal Trend Detectıon of Turkısh River Flows. Nordic Hydrology 37 (2): 165-182.

Topaloğlu, F. 2006b. Trend Detectıon of Streamflow Varıables in Turkey. Fresenius Environmental Bulletin 15(7): 644-653.

Tuna , H., Malkoc, F., Yılmaz, O. 2009. Çoruh Havzasında SYI ile Kuraklık Analizi ve Cevresel Etkileri. FORUM 2009, Doğu Karadeniz Bölgesi Hidroelektrik Enerji 50 Potansiyeli ve Bunun Ülke Enerji Politikalarındaki Yeri, 13-15 Kasım 2009, Trabzon.

Turgu, E. ve Kömüșcü, A. 2010. SYI Kuraklık Serilerinin Trend Analizi Sürdürülebilir Kalkınma ve Hayat için Meteoroloji Sempozyumu 27-28 Mayıs. Ankara

Türkeș, M. 1990. Türkiye'de Kurak Bölgeler ve Önemli Kurak Yıllar. İstanbul Üniversitesi Deniz Bilimleri ve Coğrafya Enstitüsü, Doktora Tezi, Istanbul

Türkeș, M. 2002. Spatial and temporal variations in precipitation and aridity index series of Turkey. In: Mediterranean Climate Variability and Trends, Hans- Jürgen Bolle, (ed.), Regional Climate Studies. Springer Verlag, Heidelberg, 181-213.

Türkeș, M. ve Tatlı, H. 2009. Use of the standardized precipitation index (SYI) and modified SPI for shaping the drought probabilities over Turkey. International Journal of Climatology 29: 2270-2282

Yürekli, K., Anlı, A. S., Örs, İ. ve Karahan, G. 2009. Sakarya Havzası Aylık Akımlarının Kuraklık Analizi, I. Ulusal Kuraklık ve Çölleșme Sempozyumu Bildiriler Kitabı, (779-784), Rixos Hotel, 16-18 Haziran, Toprak ve Su Kaynakları Araștırma Enstitüsü, Konya. 